\title{
Pengaruh Jenis Alat Pemanas Kandang Indukan terhadap Performan Layer Periode Starter
}

\author{
Dede Risnajati \\ Jurusan Produksi Ternak, Fakultas Pertanian, Universitas Bandung Raya \\ Jl. Bukit Raya Bawah, Ciumbuleuit, Bandung 4014
}

\begin{abstract}
ABSTRAK
Penelitian bertujuan untuk mengetahui pengaruh jenis alat pemanas kandang indukan terhadap performa layer periode starter dan untuk mengetahui jenis alat pemanas kandang indukan yang menghasilkan performa terbaik pada layer periode starter. Sebanyak 360 ekor layer periode starter dibagi ke dalam dua kelompok perlakuan jenis alat pemanas kandang indukan (masing - masing heater ducting dan heater portable). Data yang diperoleh selanjutnya dianalisis menggunakan uji t. Dari hasil percobaan dan pembahasan diperoleh simpulan bahwa jenis alat pemanas berpengaruh tidak nyata terhadap konsumsi pakan, konsumsi air minum, pertambahan bobot badan, konversi pakan, dan keseragaman bobot badan akhir pada layer periode starter
\end{abstract}

Kata kunci: heater ducting, heater portable, performan, layer, periode starter

\section{Effect of Brooder Heater Type on Performance of Laying Hens During Starter Period}

\begin{abstract}
The study aimed to determine the influence of heater type on performance of laying hens during starter period and to identify the heater that produce the best performance in layer starter period. A total of 360 layer starter period is divided into two treatment groups of brooding cage with 2 of type heaters: heater ducting and heater portable. The data were then analyzed using $t$ test. The results of the experiment indicated that the type of heater did not affect feed and consumption, body weight gain, feed conversion and uniformity of body weight of the layer starter period.
\end{abstract}

Key words: heater ducting, heater portable, performance, laying hens, starter period 


\section{PENDAHULUAN}

Periode starter merupakan masa permulaan bagi pertumbuhan dan perkembangan anak ayam. Pada masa ini terjadi pertumbuhan sel-sel dan perkembangan organ tubuh. Pertumbuhan selsel tubuh akan terlihat pada pertambahan bobt badan. Kegagalan pada periode starter dapat menurunkan performa anak ayam dan pencapaian produktivitas pada masa berikutnya.

Anak-anak ayam komersial yang baru ditetaskan membutuhkan temperatur lingkungan yang sesuai untuk pertumbuhan dan perkembangannya. Temperatur yang dingin akan menyebabkan anak ayam bergerombol dan malas untuk beraktifitas termasuk makan dan minum. Temperatur yang panas akan menyebabkan anak ayam meningkatkan meningkatkan konsumsi air minum dan mengurangi konsumsi pakan. Penurunan konsumsi pakan dapat menyebabkan asupan nutrisi dalam tubuh anak ayam berkurang sehingga menghambat pertumbuhannya.

Kebutuhan terhadap temperatur lingkungan tersebut dapat dipenuhi dengan menyediakan kandang indukan. Kandang indukan merupakan serangkaian sistem yang terdiri dari alat pemanas dan sekat yang dilengkapi tempat pakan dan air minum, litter, dan pencahayaan. Kandang indukan dapat menggunakan jenis alat pemanas yang mampu menghasilkan panas secara langsung maupun tidak langsung. Pemanasan secara langsung yaitu memanaskan udara dengan alat pemanas secara konveksi dan memasukkan udara panas tersebut ke dalam ruangan, sedangkan pemanasan tidak langsung adalah memanaskan udara yang ada di dalam ruangan dengan alat pemanas secara radiasi sehingga meningkatkan temperatur ruang. Pada metode pemanasan langsung, umumnya dipilih "heater ducting", sedangkan untuk pemanasan tidak langsung dapat memilih salah satu dari berbagai macam jenis alat pemanas antara lain gasolek, semawar, lampu bohlam, dan heater portable. Jenis bahan bakar yang digunakan beragam mulai dari minyak tanah, kayu bakar atau serutan kayu, batubara, LPG, dan listrik.

Alat pemanas kandang indukan biasanya dipilih berdasarkan kemampuannya dalam menghasilkan panas (temperatur) ruangan kandang yang sesuai dengan kebutuhan anak ayam, stabil, sebaran panasnya merata di dalam ruangan kandang, dan tidak mengeluarkan suara berisik. Heater ducting merupakan alat pemanas pada indukan yang alat pemanasnya dipasang pada saluran penyedia udara bersih sehingga menghasilkan udara panas secara merata ke seluruh ruangan kandang sedangkan heater portable merupakan alat pemanas berbentuk persegi dan umumnya diletakkan di tengah ruangan kandang dan bekerja dengan cara menyemburkan udara panas ke dalam kandang sehingga meningkatkan temperatur ruang. Penyebaran panas dari heater portable kurang merata sehingga dikhawatirkan akan menganggu pertumbuhan. Selain itu, heater portable menimbulkan polusi lingkungan yaitu memproduksi suara berisik saat bekerja. Produksi suara tersebut dikhawatirkan dapat menyebabkan anak ayam menjadi stress dan menganggu pertumbuhannya.

Penggunaan jenis alat pemanas yang berbeda pada kandang indukan serta pengaruhnya terhadap pertumbuhan ayam periode starter belum banyak diteliti. Sehubungan dengan hal tersebut, penulis tertarik untuk mengadakan penelitian mengenai Pengaruh Jenis Alat Pemanas Kandang Indukan terhadap Performa Layer Periode Starter.

\section{MATERI DAN METODE}

Penelitian ini menggunakan DOC layer strain Lohmann LSL - Classic unsexed sebanyak 360 ekor dengan bobot badan awal rata - rata 40,32 $\pm 0,95$ g/ekor dan koefisien variasinya 2,35 \%, pakan, Vita Chick, air, gula pasir, formalin, dan Medisep.

Peralatan yang digunakan adalah dua buah ruangan percobaan model close house, 36 cages battery, heater ducting, heater portable, kompor listrik, timer, kertas 
dextrose, plastik bening, timbangan, dan Thermohygrometer.

Metode penelitian yang digunakan adalah eksperimen pola observasi berpasangan. Analisis yang digunakan adalah uji t.

\section{HASIL DAN PEMBAHASAN}

Rataan konsumsi pakan, konsumsi air minum, pertambahan bobot badan, konversi pakan, dan keseragaman bobot badan layer periode starter selama tiga minggu percobaan dapat dilihat pada Tabel 1.

\section{Konsumsi pakan}

Rataan jumlah pakan yang dikonsumsi layer periode starter selama percobaan menggunakan heater ducting adalah 13,92 \pm 7,74 gram/ekor/hari dan yang menggunakan heater portable adalah 13,71 $\pm 7,16$ gram/ekor/hari masing - masing lebih rendah dari 16,48 \% dan 17,74 \% dari standar konsumsi pakan layer management guide Lohmann LSL - Classic (2007) yaitu 16,67 gram/ekor/hari. Hasil analisis uji $t$ menunjukkan jenis alat pemanas berpengaruh tidak nyata $(\mathrm{P}>0.05)$ terhadap konsumsi pakan. Hal ini diduga karena tidak berbedanya panas yang dihasilkan dari masing - masing alat pemanas yang digunakan. Dengan kata lain, heater ducting dan heater portable dapat memberikan panas yang sesuai dengan kebutuhan layer periode starter dalam kandang indukan. Panas yang dihasilkan kedua alat pemanas telah diatur sesuai dengan standar strain sehingga temperatur yang dibutuhkan oleh anak ayam tercapai. Krom (2002) menyatakan bahwa dianjurkan untuk mengatur temperatur alat pemanas sesuai dengan standar masing - masing strain terutama pada hari - hari pertama kehidupan ayam. Dengan kondisi temperatur lingkungan yang nyaman, anak ayam dapat melakukan aktifitas makan yang baik. Temperatur yang ideal akan menyebabkan anak ayam beraktifitas secara normal dan ayam tersebar secara merata ke seluruh ruangan (Anonimous, 2006).
Rataan kisaran panas yang dihasilkan dari heater ducting dan heater portable masing - masing adalah $29,29{ }^{\circ} \mathrm{C}$ dan 28,79 ${ }^{\circ} \mathrm{C}$. Adanya produksi suara yang berasal dari heater portable ternyata tidak berpengaruh pada anak ayam, terbukti dengan nafsu makan yang tinggi. Hal ini disebabkan karena anak ayam sudah terbiasa mendengarkan suara berisik yang berasal dari alat pemanas sejak pertama kali berada dalam kandang indukan dan pemberian vitamin selama pemeliharaan periode starter. Dunford (1999) menyatakan bahwa vitamin $\mathrm{C}$ yang ditambahkan dalam air minum akan meningkatkan konsumsi pakan sekaligus mengurangi stress.

\section{Konsumsi air minum}

Jumlah air minum yang dikonsumsi layer periode starter untuk heater ducting adalah 24,63 \pm 13,62 ml/ekor/hari dan heater portable adalah $24,48 \pm 12,4$ gram/ekor/hari. Hasil uji t menunjukkan bahwa heater ducting dan heater portable berpengaruh tidak nyata $(\mathrm{P}>0.05)$ terhadap konsumsi air minum. Hal ini diduga karena kedua alat pemanas menghasilkan panas yang stabil sehinggaa temperatur pada kedua ruangan kandang sesuai dengan kebutuhan anak ayam, maka konsumsi air minumnya tidak berbeda pula. Selain itu, jenis dan konsumsi pakan yang berbeda tidak nyata menyebabkan konsumsi air minum tidak berbeda pula karena anak ayam mengkonsumsi sesuai dengan pola konsumsi pakannya. Hal tersebut sesuai dengan pernyataan dari Hoppe (1999) yang menyatakan bahwa faktor biologis yang menentukan banyaknya air yang masuk ke dalam tubuh adalah kepadatan, diare karena infeksi, atau osmotik, konsumsi pakan, dan stress terutama stress panas. Lebih jauh ditegaskan bahwa pada temperatur ambient normal (temperatur nyaman) unggas mengkonsumsi dua kali lebih banyak air dibanding pakan. Suprijatna, dkk., (2005) menambahkan bahwa setiap mengkonsumsi 1 gram pakan, ayam dan kalkun harus mengonsumsi sekitar 2-2,25 gram air pada periode starter dan grower, sedangkan saat periode layer sekitar 1,5-2 gram. 
Tabel 1. Rataan konsumsi pakan, konsumsi air minum, pertambahan bobot badan, konversi pakan, dan keseragaman bobot badan selama percobaan

\begin{tabular}{lcc}
\hline \multicolumn{1}{c}{ Peubah } & Heater Ducting & Heater Portable \\
\hline Konsumsi pakan (gram/ekor/hari) & $13,92 \pm 7,74$ & $13,71 \pm 7,16$ \\
Konsumsi air minum (ml/ekor/hari) & $24,63 \pm 13,62$ & $24,48 \pm 12,4$ \\
Pertambahan bobot badan (gram/ekor) & $141,85 \pm 5,69$ & $139,93 \pm 6,43$ \\
Konversi pakan & $2,061 \pm 0,04$ & $2,058 \pm 0,02$ \\
Keseragaman bobot badan (\%) & $93,52 \pm 1,01$ & $93,19 \pm 0.24$ \\
\hline
\end{tabular}

\section{Pertambahan bobot badan}

Rataan pertambahan bobot badan layer periode stater selama percobaan menggunakan heater ducting adalah 141,85 \pm 5,69 gram/ekor dan yang menggunakan heater portable adalah $139,93 \pm 6,43$ gram/ekor, masing - masing lebih rendah $3,29 \%$ dan 4,6 \% dari standar pertambahan bobot badan layer management guide Lohmann LSL - Classic (2007), yaitu 146,68 gram/ekor. Hasil analisis dengan uji $t$ menunjukkan bahwa penggunaan heater ducting dan heater portable berpengaruh tidak nyata $(\mathrm{P}>0.05)$ terhadap pertambahan bobot badan. Hal ini merupakan akibat dari konsumsi pakan yang juga berbeda tidak nyata. Leeson dan Summers (2001) menyatakan bahwa pertambahan bobot badan sangat dipengaruhi oleh konsumsi pakan.

\section{Konversi pakan}

Rataan pertambahan bobot badan layer periode stater selama percobaan menggunakan heater ducting adalah 2,061 \pm 0,04 dan yang menggunakan heater portable adalah 2,058 \pm 0,02, masing - masing lebih rendah 13,63 \% dan 13,75 \% dari standar konversi pakan layer management guide Lohmann LSL - Classic (2007), yaitu 2,39. Hasil analisis dengan uji t menunjukkan bahwa penggunaan heater ducting dan heater portable berpengaruh tidak nyata $(\mathrm{P}>$ 0.05) terhadap konversi pakan. Hal ini diduga sebagai akibat dari konsumsi pakan dan pertambahan bobot badan yang berbeda tidak nyata. Rasyaf (1993) menyatakan konversi pakan adalah perbandingan antara jumlah pakan yang dikonsumsi dengan pertambahan bobot badan dalam jangka waktu tertentu. Ditambahkan oleh Card dan Nesheim (1972) bahwa nilai konversi pakan yang tinggi menunjukkan jumlah pakan yang dibutuhkan untuk menaikkan bobot badan semakin banyak dan efisiensi pakan semakin rendah.

\section{Keseragaman bobot badan}

Rataan keseragaman bobot badan layer periode stater selama tiga minggu percobaan menggunakan heater ducting adalah 93,52 \pm $1,01 \%$ dan yang menggunakan heater portable adalah 93,19 $\pm 0.24 \%$. Masing - masing pemanas ternyata menghasilkan tingkat keseragaman yang baik karena nilainya lebih besar dari $80 \%$ sesuai dengan pendapat Anonimous (2009) bahwa ayam dengan tingkat keseragaman baik, yaitu setidaknya $80 \%$, akan menyebabkan ayam memiliki bobot badan, kerangka tubuh dan kedewasaan kelamin yang sama.

Hasil analisis dengan uji t menunjukkan bahwa penggunaan heater ducting dan heater portable berpengaruh tidak nyata $(\mathrm{P}>0,05)$ terhadap keseragaman bobot badan. Hal ini diduga karena kedua alat pemanas mampu menyebarkan panas merata ke seluruh ruangan kandang. Panas yang merata akan menciptakan kondisi kandang yang nyaman untuk pertumbuhan dan perkembangan anak ayam. Anonimous (2009a) menyatakan bahwa faktor yang perlu diperhatikan agar keseragaman tercapai antara lain: (a) kualitas DOC, (b) kepadatan kandang, (c) tempat pakan dan minum, (d) kandang yang nyaman, dan (e) program kesehatan yang tepat. Lebih lanjut dikemukakan bahwa ayam akan tumbuh dan 
berproduksi secara optimum jika dipelihara di kandang yang nyaman. Untuk itu indukan harus diberikan cukup pemanas untuk menciptakan panas yang merata (Santoso, 2000).

Haris (2007) menyatakan bahwa sistem aliran udara panas (heater ducting) menghasilkan distribusi panas yang baik dan menyeluruh di dalam kandang. Penyebaran panas yang kurang merata pada heater portable ternyata tidak berpengaruh pada keseragaman bobot badan ayam karena rataan temperatur yang dicapai oleh pemanas masih berada dalam kisaran standar temperatur dari layer management guide Lohmann LSL - Classic (2007) sehingga anak ayam pun masih memperoleh temperatur yang optimum untuk pertumbuhan dan perkembangannya.

\section{KESIMPULAN}

Jenis alat pemanas pada kandang indukan tidak berpengaruh terhadap konsumsi pakan, konsumsi air minum, pertambahan bobot badan, konversi pakan dan keseragaman bobot badan layer periode starter.

\section{DAFTAR PUSTAKA}

Anonimous. 2002. Choosing a Heating System. www.energysmart.com.au. Diunduh 08/09/2009.

Anonimous. 2006. Saat Masa Awal Menjadi Penentu. http://infomedion.co.id. Diunduh 04/10/2009.
Anonimous. 2009. Arti Pentingnya Keseragaman Ayam Petelur. http://infomedion.co.id. Diunduh 04/11/2009.

Card, L.E. dan M.C. Nesheim. 1972. Poultry Production. $11^{\text {th }}$ Edition. Lea and Febiger. Philadelphia. California.

Dunfod, I.S. 1999. Mengurangi Stress Panas pada Itik. Diterjemahkan dari Minimishing Heat Stress in Ducks. Poultry International. $38^{\text {th }}$ Edition.

Haris, S. 2007. Pemanas Brooding, Pilih yang Mana? Charoen Pokphand Buletin Service. Edisi Oktober. Nomor 94/Tahun VIII.

Hoppe, P.P. 1999. Litter Basah pada Ayam Pedaging. Diterjemahkan dari Wet Litter in Broilers. Poultry International. $38^{\text {th }}$ Edition.

Krom. 2002. Menjaga Konsumsi Pakan Broiler. http://www.poultryindonesia.com. Diunduh 03/08/09.

Layer Management Guide Lohmann LSL - Classic. 2007. Layer Management Guide. Germany.

Leeson, S dan J. D. Summers. 2001. Nutrition of the Chicken. $4^{\text {th }}$ Edition. University Brooks. Canada.

Rasyaf, M. 1993. Beternak Ayam Pedaging. Edisi kelima. Penebar Swadaya. Jakarta.

Santoso, U. 2000. Menciptakan Broiler yang Seragam. Jurnal Urip Santoso. Menuju Pemikiran Mandiri. Poultry Indonesia. Edisi Maret.

Suprijatna, E., U. Atmomarsono, dan R. Kartasujana. 2005. Ilmu Dasar Ternak Unggas. Penerbit Penebar Swadaya: 8-9. 